\title{
KEBIASAAN SARAPAN PAGI DENGAN STATUS GIZI ANAK SEKOLAH DASAR
}

\author{
Busyra Hanim $^{\bowtie}$, Ingelia, Dany Ariyani \\ Program Studi S1 Kebidanan dan Profesi Bidan STIKes Payung Negeri Pekanbaru
}

\section{ARTICLE INFO}

Article history

Submitted : 2021-12-20

Revised : 2021-12-28

Accepted : 2022-01-25

\section{Keywords:}

Breakfast habits

Nutritional status

Primary School Children

\section{Kata Kunci:}

Kebiasaan sarapan pagi

Status gizi

Anak Sekolah Dasar

\section{Corresponding Author:}

Busya Hanim

Prodi S1 Kebidanan STIKes Payung Negeri Pekanbaru

Telp. 082169067003

Email: hanim.busyra@gmail.com

\begin{abstract}
Nutritional status is an indicator that reflects the level of welfare. Malnutrition in the form of deficiency and excess nutrition is one of the health problems in Indonesia. Riskesdas 2018 show the prevalence of nutritional status (BMI/U) in Indonesian children aged $5-12$ years who are very thin $2.4 \%$, lean $6.8 \%$, fat $10.8 \%$, and obese $9.2 \%$. School-age children are in a period of rapid growth, in dire need of quality nutrients in relatively large quantities. In addition, nutrients are also used to improve the ability of children's brains to participate in learning activities. Eating breakfast in the morning is a healthy behavior to achieve balanced nutrition for a healthy, active, and intelligent life, but there are still many who do not fulfill their nutritional needs through breakfast. The purpose of this study was to determine the relationship between breakfast habits and the nutritional status of children at Sekolah Dasar Negeri 48 Pekanbaru City. The research method used was quantitative with a cross-sectional design, conducted from October to December 2021. The sample in this study was all fifth-grade students at SD Negeri 48 Pekanbaru City, a total of 53 people. Data analysis was carried out using a chi-square statistical test, thus concluded that there is no relationship between breakfast habits and the nutritional status of students at SD Negeri 48 Pekanbaru City with a p-value of 0.670 . Further research is needed to determine another factor affecting the nutritional status of students.

Status gizi merupakan indikator yang mencerminkan tingkat kesejahteraan. Malnutrisi dalam bentuk kekurangan dan kelebihan gizi merupakan salah satu masalah kesehatan di Indonesia. Hasil Riskesdas 2018 menunjukkan prevalensi status gizi (IMT/U) pada anak Indonesia usia 5 - 12 tahun sangat kurus sebanyak 2,4\%, kurus sebanyak 6,8\%, gemuk $10,8 \%$, dan obesitas sebanyak $9,2 \%$. Anak usia sekolah berada pada masa pertumbuhan pesat, sangat membutuhkan zat gizi berkualitas dan dalam jumlah relatif besar. Selain untuk pertumbuhan, zat gizi juga digunakan untuk meningkatkan kemampuan otak anak dalam mengikuti kegiatan belajar. Salah satu sumber pemenuhan zat gizi pada anak sekolah adalah dengan sarapan pagi. Sarapan pagi merupakan bagian dari perilaku sehat untuk mewujudkan gizi seimbang bagi hidup sehat, aktif, dan cerdas, namun masih banyak yang belum memenuhi kebutuhan gizi dipagi hari melalui sarapan pagi yang sehat. Tujuan penelitian ini adalah untuk mengetahui hubungan kebiasan sarapan pagi dengan status gizi anak Sekolah Dasar Negeri 48 Kota Pekanbaru tahun 2021. Jenis penelitian adalah kuantitatif dengan desain cross sectional. Penelitian dilakukan pada bulan Oktober sampai Desember 2021. Populasi penelitian adalah seluruh siswa kelas V di SD Negeri 48 Kota Pekanbaru berjumlah 53 orang. Teknik sampling secara sampling jenuh, seluruh populasi dijadikan sampel sebanyak 53 orang. Analisis data dilakukan secara univariat dan bivariat. Analisis data bivariat menggunakan uji statistic chi-square. Kesimpulan penelitian ini bahwa tidak ada hubungan antara kebiasaan sarapan pagi dengan status gizi siswa Sekolah Dasar Negeri 48 Kota Pekanbaru dengan nilai $\mathrm{p}=0,670$. Perlu dilakukan penelitian lebih lanjut untuk mengetahui faktor lain yang mempengaruhi status gizi siswa.
\end{abstract}

This is an open access article under the CC BY-SA license:

\section{PENDAHULUAN}

Anak sekolah adalah golongan yang berusia antara $7-12$ tahun. Golongan ini memiliki karakteristik mulai mengembangkan kemandirian dan menentukan batasan dan norma. Variasi individu mulai dikenali pada perumbuhan dan perkembangan, pola aktivitas, 
kebutuhan zat gizi, perkembangan kepribadian, serta asupan makanan (Pritasari et al., 2017).

Kehidupan anak sebagai aset sumber daya manusia dan generasi penerus perlu mendapat perhatian. Kecukupan gizi merupakan salah satu faktor terpenting dalam pengembangan anak. Kecukupan gizi sangat memengaruhi kecerdasan dan produktivitas anak sehari-hari. Namun pada kenyataannya, permasalahan gizi anak di Indonesia masih cukup tinggi. Tercatat persentase stunting sebesar $37,1 \%$, anak dengan gizi kurang sebesar $19,6 \%$, dan anak dengan gizi lebih sebanyak $11,9 \%$ (Sekretariat Jenderal Kementerian Kesehatan RI, 2016).

Hasil penelitian Judarwanto (2016) mendapatkan bahwa anak usia sekolah mengalami kesulitan makan sebesar 33,6\%, sebagian besar $(79,2 \%)$ telah berlangsung lebih dari 3 bulan, dan masalah makan ini dipengaruhi oleh gaya pola asuh dari orang tua (Judarwanto, 2016).

Pada usia sekolah, anak akan melakukan banyak aktivitas fisik maupun mental, seperti: bermain, belajar, berolahraga, dan lain-lain. Zat gizi yang diberikan akan membantu dalam meningkatkan kesehatan tubuh sehingga sistem imun tubuh berkembang dengan baik dan tidak mudah terserang penyakit. Anak usia sekolah membutuhkan lebih banyak energi dan zat gizi dibanding dengan balita. Memerlukan tambahan energi, protein, kalsium, fluor, zat besi karena pertumbuhan pada usia ini berlangsung pesat dan aktivitas main bertambah. Untuk memenuhi energi dan zat gizi, kadang anak makan hingga 5 kali sehari. Namun anak tetap dilatih untuk makan 3 kali sehari dengan menu gizi yang tinggi yaitu sarapan, makan siang, dan makan malam disertai 2 kali makanan selingan. Dengan memenuhi kebutuhan tersebut dapat mencegah terjadinya masalah gizi pada anak sekolah, baik gizi kurang maupun kegemukan pada anak (Pritasari et al., 2017).

Sarapan merupakan kegiatan makan dan minum yang dilakukan pada pagi hari, dimulai dari pukul 06.00 sampai dengan pukul 09.00 pagi. Melalui aktivitas sarapan pagi dapat dikonsumsi makanan yang mengandung gizi seimbang dan memenuhi $15-30 \%$ dari energi total dalam sehari yang dilakukan pada pagi hari sebelum beraktivitas. Manusia membutuhkan sarapan pagi, karena dalam sarapan pagi diharapkan dapat memenuhi kecukupan energi yang diperlukan untuk jam pertama beraktivitas (Hardinsyah \& Aries, 2016). Kementerian Kesehatan RI telah memperhatikan betapa pentingnya sarapan pagi bagi setiap orang. Dengan menjadikan "Pembiasaan Sarapan Pagi" menjadi salah satu bagian dari pedoman dalam 10 Pesan Umum Gizi Seimbang yang dikonsumsi sehari-hari.

Menurut Brown et al sarapan pagi memberi manfaat berupa kemampuan daya ingat (kognitif) yang lebih baik; memiliki daya juang belajar dan konsentrasi atau perhatian yang lebih baik; memiliki kemampuan membaca, berhitung dan skor kemampuan bahasa dan logika lebih baik; anak jarang sakit, pusing, sakit telinga dan sakit perut; serta memiliki stamina dan disiplin yang lebih baik. Hal ini didukung oleh berbagai hasil penelitian yang telah membuktikan manfaat dari sarapan pagi seperti memiliki daya konsentrasi lebih tinggi; lebih gesit dan aktif dalam beraktivitas; lebih sehat dan tidak lemas sehingga tidak mudah terkena penyakit (Perdana \& Hardinsyah, 2016). Hasil studi Rahma (2016) menunjukkan bukti bahwa sebagian besar dampak positif dari sarapan pagi pada perilaku anak dalam mengerjakan tugas sekolahnya (Adolphus, 2016).

Usia anak sekolah merupakan usia yang membutuhkan perhatian khusus dalam hal gizi dan kesehatan. Di usia ini, anak sudah bisa menentukan pilihan makanan dan minuman yang mereka inginkan (Wiradnyani et al., 2019).

Saat sarapan dianjurkan mengonsumsi makanan yang memiliki kadar serat tinggi, cukup protein dan rendah lemak. Jenis makanan ini dapat membuat seseorang tetap kenyang hingga waktu makan siang. Banyak anak-anak yang lebih menyukai makanan jajanan yang hanya mengandung karbohidrat dan garam yang hanya akan membuat cepat kenyang dan mengganggu nafsu makannya. Sehingga perlu pengawasan orang tua agar tidak salah dalam memilih jenis makanan yang dikonsumsi. Penelitian Jackson et al. (2016) mendapatkan adanya hubungan positif antara sarapan dengan status zat besi (Jackson et al., 2016).

Pada usia sekolah anak sudah mulai lepas dari pengawasan orang tua dan bergaul dengan teman sekolahnya. Masa usia ini sangat memerlukan perhatian terutama dalam hal membiasakan anak untuk sarapan pagi sebelum berangkat sekolah. Ini menjadi kewajiban orang 
tua dalam menjamin terpenuhinya hak anak untuk memperoleh makanan secara cukup dan berkualitas. Jika dilengkapi dengan pola asuh yang baik makan anak akan tumbuh berkembang secara optimal menjadi generasi berkualitas dan tangguh (Pritasari et al., 2017).

Anak sekolah mempunyai fisik yang kuat, aktif, serta tidak bergantung pada orang tua. Aktivitas anak sekolah seperti proses belajar yang rutin dilakukan setiap hari, diikuti dengan kegiatan bermain, berolahraga, berinteraksi dengan lingkungan yang semuanya membutuhkan energi. Kebutuhan gizi anak usia sekolah relatif lebih besar daripada anak dibawahnya, karena pertumbuhan tubuh lebih cepat terutama dalam penambahan tinggi badan. Pada anak usia 10 - 12 tahun, kebutuhan sudah terbagi menurut jenis kelaminnya. Anak lakilaki lebih banyak aktivitas fisik sehingga memerlukan energi yang lebih banyak dibandingkan anak perempuan. Anak perempuan sudah memiliki siklus haid sehingga memerlukan lebih banyak protein, zat besi dari usia sebelumnya (Miko \& Dina, 2016).

Masyarakat Indonesia masih banyak yang belum membiasakan sarapan pagi dengan benar. Jika tidak sarapan pagi dapat menimbulkan dampak berupa menurunkan produktivitas, kualitas proses belajar menurun, menyebabkan kegemukan, dan meningkatkan risiko jajan yang tidak sehat (Direktorat Jenderal Bina Gizi dan KIA, 2014). Berdasarkan uraian tersebut, maka penulis ingin meneliti hubungan kebiasaan sarapan pagi dengan status gizi anak Sekolah Dasar Negeri 48 Pekanbaru.

\section{METODE PENELITIAN}

\section{Jenis Penelitian}

Jenis penelitian ini adalah analitik dengan desain cross-sectional. Peneliti melakukan observasi pada variabel kebiasaan sarapan pagi dan status gizi pada murid Sekolah Dasar 48 Kota Pekanbaru pada waktu bersamaan.

\section{Lokasi dan Waktu Penelitian}

Penelitian ini berlokasi di Sekolah Dasar Negeri 48 Kota Pekanbaru pada Oktober - Desember 2021.

\section{Populasi dan Sampel}

Kegiatan penelitian dilaksanakan pada masa pandemi Covid-19 yang berdampak pada pemberlakuan masa belajar siswa di Sekolah
Dasar. Dengan penerapan pertemuan tatap muka terbatas, sehingga penelitian ini hanya dapat dilakukan pada siswa kelas 5 .

Populasi penelitian adalah seluruh siswa kelas 5 SD 48 Kota Pekanbaru berjumlah 53 orang. Teknik pengambilan sampel secara sampling jenuh, dimana semua anggota populasi dijadikan sampel yang berjumlah 53 orang.

\section{Pengumpulan Data}

Data yang digunakan dalam penelitian ini adalah data primer dan data sekunder. Pengumpulan data primer dilakukan langsung oleh peneliti saat melakukan pengukuran dan wawancara. Penilaian kebiasaan sarapan pagi responden ditentukan melalui wawancara pada masing-masing responden. Instrumen yang digunakan adalah lembar kuesioner yang berisi karakteristik responden meliputi usia, jenis kelamin, tempat/tanggal lahir, informasi tentang kebiasaan sarapan pagi meliputi frekuensi sarapan pagi dalam satu minggu, ketersediaan sarapan, waktu sarapan serta pemilihan dan variasi makanan. Kuesioner kebiasaan sarapan pagi yang peneliti gunakan merupakan kuesioner yang teruji validitas dan reliabilitasnya pada penelitian sebelumnya.

Penilaian status gizi responden dilakukan melalui pengukuran antropometri yaitu berat badan dan tinggi badan responden. Berat badan diukur menggunakan timbangan injak. Timbangan diletakkan pada tempat datar dan sepatu serta benda berat dilepaskan. Tinggi badan diukur dengan menggunakan microtoice yang diletakkan pada dinding yang datar. Saat pengukuran tinggi badan, responden berdiri tegak dengan pandangan lurus ke depan, bahu rata, kepala, punggung, bokong, betis dan tumit kaki menempel ke dinding. Status gizi responden ditentukan dengan menghitung IMT/U (Kemenkes RI, 2020).

\section{Pengolahan dan Analisis Data}

Pengolahan data melalui tahapan editing, coding, data entry, dan tabulating. Pengolahan data dilakukan menggunakan program SPSS. Dilanjutkan dengan analisis data secara univariat dan bivariat.

Analisis secara univariat dilakukan untuk mendeskripsikan tiap variabel penelitian pada tabel distribusi frekuensi. Analisis bivariat dilakukan untuk melihat apakah ada hubungan antara variabel dependen dan independen. Hubungan dinilai dengan menggunakan uji chi- 
square dengan kriteria nilai $\mathrm{p}<0,05$ menandakan ada hubungan, jika nilai $\mathrm{p}>0,05$ berarti tidak ada hubungan.

\section{HASIL PENELITIAN}

Berdasarkan tabel 1. diketahui bahwa mayoritas responden berumur antara $11-12$ tahun sebanyak 28 orang (52,9\%). Pada kategori jenis kelamin mayoritas responden berjenis kelamin perempuan sebanyak 27 orang $(50,9 \%)$.

Tabel 1. Distribusi Frekuensi Responden berdasarkan Karakteristik Umur, Jenis Kelamin, Kebiasaan Sarapan Pagi, dan Status Gizi di SD 48 Kota Pekanbaru

\begin{tabular}{lcc}
\hline \multicolumn{1}{c}{ Kategori } & Frekuensi (n) & Persen (\%) \\
\hline Umur & 21 & \\
$<11$ tahun & 28 & 39,6 \\
$11-12$ tahun & 4 & 52,9 \\
$>12$ tahun & 26 & 7,5 \\
\hline Jenis Kelamin & 27 & 49,1 \\
$\quad$ Laki-laki & & 50,9 \\
$\quad$ Perempuan & 45 & \\
Kebiasaan Sarapan Pagi & 7 & 84,9 \\
Baik & 1 & 13,2 \\
Cukup & & 1,9 \\
Kurang & 23 & 43,39 \\
\hline Status Gizi & 21 & 39,62 \\
Status Gizi Baik & 9 & 16,99 \\
Status Gizi lebih & $\mathbf{5 3}$ & $\mathbf{1 0 0}$ \\
Status Gizi Obesitas & & \\
\hline$\quad$ Jumlah &
\end{tabular}

Mayoritas responden telah menerapkan dengan baik kebiasaan sarapan pagi sebanyak 45 orang $(84,9 \%)$. Namun masih ditemukan responden dengan kebiasaan sarapan pagi dengan kategori cukup 7 orang $(13,2 \%)$ dan kurang 1 orang $(1,9 \%)$. Berdasarkan status gizi responden terbagi atas tiga kategori, yaitu gizi baik (normal), gizi lebih (gemuk), dan obesitas. Mayoritas responden memiliki status gizi lebih yang terdiri dari gemuk sebanyak 21 orang $(39,62 \%)$ dan obesitas sebanyak 9 orang $(16,99 \%)$.

Pada tabel 2. diketahui bahwa masih ada responden yang kadang-kadang sarapan pagi ( 3 - 4 kali seminggu) sebanyak 14 orang $(26,4 \%)$ dan jarang/tidak pernah sebanyak 9 orang (17\%). Masih ditemukan 5 orang responden $(9,4 \%)$ yang sarapan pagi hanya setiap akan berangkat sekolah saja, dan sebanyak 6 orang $(11,4 \%)$ responden sarapan pagi saat lapar saja. Diketahui masih ada responden 17 orang $(32,1 \%)$ yang sarapan pagi ketika merasa lapar pada waktu yang tidak menentu. Didapatkan masih ada 7 orang
$(13,20 \%)$ responden dengan keluarga yang kadang-kadang menyediakan sarapan di rumah. Diketahui jenis makanan yang dikonsumsi saat sarapan masih ada 2 orang responden $(3,8 \%)$ dengan makanan tidak lengkap, dan 3 orang $(5,6 \%)$ minuman saja. Diketahui masih ada 13 orang $(24,5 \%)$ responden yang kadang-kadang jenis makanan sarapan paginya berganti.

Analisis ini menggunakan uji Chi Square dengan tingkat kepercayaan 0,05 $(\alpha=0,05)$, jika didapatkan $p$ value $>0,05$ berarti tidak berhubungan. Berdasarkan Tabel 3 . didapatkan dari 20 orang responden dengan kebiasaan sarapan pagi baik, mayoritas memiliki status gizi lebih, yaitu 17 orang $(37,8 \%)$ gemuk, sebanyak 8 orang $(17,8 \%)$ obesitas. Hanya 20 orang responden dengan kebiasaan sarapan pagi baik memiliki status gizi baik (normal) pula. Diketahui dari 7 responden dengan kebiasaan sarapan pagi yang cukup, mayoritas memiliki status gizi lebih (gemuk) sebanyak 4 orang $(57,1 \%)$. Serta 1 responden dengan kebiasaan sarapan pagi kurang memiliki status gizi baik. Dari hasil uji 
korelasi didapatkan nilai $\mathrm{p}>0,05$ yaitu $\mathrm{p}=0,670$ yang berarti tidak terdapat hubungan antara kebiasaan sarapan pagi dengan status gizi responden.

Tabel 2. Distribusi Frekuensi Responden Berdasarkan Indikator Kebiasaan Sarapan Pagi di SD 48 Kota Pekanbaru

\begin{tabular}{lcc}
\hline Indikator Kebiasaan Sarapan Pagi & n & $\%$ \\
\hline Frekuensi Sarapan & 30 & 56,6 \\
a. Sering & 14 & 26,4 \\
b. Kadang-kadang & 9 & 17 \\
c. Jarang/tidak pernah & & \\
\hline Pelaksanaan Sarapan & 42 & 79,2 \\
a. Setiap pagi & 5 & 9,4 \\
b. Setiap hari sekolah & 6 & 11,4 \\
c. Saat lapar saja & & \\
\hline Waktu Sarapan & 36 & 67,9 \\
a. Jam 6-9 pagi & 17 & 32,1 \\
b. Saat lapar & & \\
\hline Ketersediaan Sarapan & 46 & 86,79 \\
a. Selalu & 7 & 13,20 \\
b. Kadang-kadang & & \\
\hline Pemilihan Makanan & 48 & 90,6 \\
a. Makanan lengkap & 2 & 3,8 \\
b. Makanan tidak lengkap & 3 & 5,6 \\
c. Minuman saja & & \\
\hline Keragaman Makanan & 40 & 75,5 \\
a. Ya & 13 & 24,5 \\
b. Kadang-kadang &
\end{tabular}

\section{PEMBAHASAN}

\section{Kebiasaan Sarapan Pagi}

Hasil penelitian Aghadiati (2019) tentang Hubungan Pengetahuan Ibu dengan Pola Menu Sarapan dan Kebiasaan pada Anak Sekolah Dasar menunjukkan bahwa terdapat hubungan signifikan antara pengetahuan gizi ibu dengan kebiasaan sarapan anak dan hubungan signifikan antara tingkat pengetahuan ibu dengan pola menu sarapan.

Pengetahuan merupakan hal penting dalam terbentuknya perilaku seseorang. Faktor pengetahuan gizi anak, ketersediaan makanan, dukungan keluarga, dan peran guru memiliki hubungan bermakna dengan perilaku sarapan pagi. Kebiasaan sarapan pagi pada siswa SD pada penelitian ini baik, yaitu $84,9 \%$, ketersediaan sarapan pagi selalu yaitu $86,79 \%$. Didapatkan ketersediaan makanan untuk sarapan pagi merupakan varabel yang paling dominan berhubungan dengan perilaku sarapan pagi dengan nlai $\mathrm{OR}=5,673$.
Orang tua terutama ibu memiliki peran yang berpengaruh besar dalam membentuk kebiasaan sarapan anak. Anak usia sekolah dasar masih membutuhkan bimbingan orang tua dalam membentuk kebiasaan sehari-hari mereka. Sarapan pada anak usia ini memerlukan orang dewasa yang menyiapkannya, pada umumnya dilakukan oleh ibu. Selain membentuk kebiasaan sarapan, ibu juga berperan dalam menentukan menu sarapan yang baik untuk anak (Aghadiati, 2019).

Ketersediaan makanan untuk sarapan pagi di rumah, merupakan hal yang sangat penting dalam memfasilitasi, mendukung anak agar terbiasa sarapan pagi. Jika makanan tersedia setiap pagi untuk sarapan pagi anak, hal ini secara psikologis akan membentuk pola makan sehat anak. Hasil penelitian ini juga menunjukkan bahwa tidak terdapat hubungan yang signifikan antara pola menu sarapan dengan kebiasaan anak (Aghadiati, 2019).

Mengonsumsi makanan dengan kandungan gizi seimbang menjamin 
terpenuhinya kebutuhan tubuh beserta aktivitasnya. Anak sekolah mengalami pertumbuhan fisik, kecerdasan, mental dan emosional yang sangat cepat. Makanan yang mengandung unsur gizi sangat diperlukan untuk proses tumbuh kembang ini. Dengan mengonsumsi makanan yang cukup gizi secara teratur, anak dapat tumbuh sehat sehingga mampu mencapai prestasi belajar yang tinggi dan kebugaran untuk dapat mengikuti semua aktivitas sehingga menjadi sumber daya manusia yang berkualitas (Wiradnyani et al., 2019).

Tabel 3. Hubungan Kebiasaan Sarapan Pagi dengan Status Gizi di SD 48 Kota Pekanbaru

\begin{tabular}{|c|c|c|c|c|c|c|c|c|c|}
\hline \multirow{3}{*}{$\begin{array}{c}\text { Kebiasaan } \\
\text { Sarapan Pagi }\end{array}$} & \multicolumn{6}{|c|}{ Status Gizi } & \multirow{2}{*}{\multicolumn{2}{|c|}{ Jumlah }} & \multirow{3}{*}{$p$} \\
\hline & \multicolumn{2}{|c|}{ Baik } & \multicolumn{2}{|c|}{ Lebih } & \multicolumn{2}{|c|}{ Obesitas } & & & \\
\hline & $\mathrm{n}$ & $\%$ & $\mathrm{n}$ & $\%$ & $\mathbf{n}$ & $\%$ & $\mathbf{N}$ & $\%$ & \\
\hline Baik & 20 & 44,4 & 17 & 37,8 & 8 & 17,8 & 45 & 100 & \\
\hline Cukup & 2 & 28,6 & 4 & 57,1 & 1 & 14,3 & 7 & 100 & 0,670 \\
\hline Kurang & 1 & 100 & 0 & 0 & 0 & 0 & 1 & 100 & \\
\hline Jumlah & 23 & 43,4 & 21 & 39,6 & 9 & 17,1 & 53 & 100 & \\
\hline
\end{tabular}

Sumber: Data Primer Tahun 2021

\section{Status Gizi}

Temuan ini sesuai dengan hasil Riskesdas 2018 yang menunjukkan status gizi anak umur $5-12$ tahun dengan prevalensi gemuk sebesar $10,8 \%$ dan obesitas sebesar 9,2 $\%$, lebih banyak dari anak dengan status gizi kurus $9,2 \%$. Status gizi adalah keseimbangan antara asupan dan kebutuhan zat gizi dalam tubuh (Hayati et al., 2018). Gizi baik merupakan salah satu faktor terpenting dalam mempertahankan hidup, menjaga kesehatan, serta perkembangan di masa kini dan generasi yang akan datang, gizi pada individu dapat dilihat melalui status gizi. Kekurangan dan kelebihan gizi pada dasarnya terjadi akibat makanan sehari-hari yang mengandung zat gizi dalam jenis dan jumlah yang tidak sesuai dengan kebutuhan tubuh, dengan memperhatikan prinsip keragaman makanan, keamanan makanan, pentingnya pola hidup dan berolahraga dan berat badan ideal.

Menunda sarapan dapat menyebabkan kekurangan zat gizi di pagi hari sehingga meningkatkan malnutrisi. Bahkan menunda sarapan di sisi lain dapat mengakibatkan konsumsi makanan yang berlebihan di waktu malam terutama saat makan malam sehingga menyebabkan obesitas (Wiradnyani et al., 2019). Anak yang sering melewatkan sarapan memiliki lingkar pinggang, total kolesterol dan konsentrasi kolesterol LDL yang lebih tinggi, sehingga berisiko terkena penyakit kardiovaskuler dan diabetes melitus.
Masa pandemi Covid-19 dengan penerapan pembelajaran di rumah menyebabkan perubahan dalam kehidupan sehari-hari. Menjaga pola makan gizi seimbang yang sehat sangat penting dalam meningkatkan sistem kekebalan tubuh yang baik. Dilengkapi dengan rutin berolah raga dan mencuci tangan dengan air mengalir dan sabun (Kemenkes RI, 2020) Berdasarkan hasil penelitian ini didapatkan banyaknya murid dengan status gizi lebih. Kurangnya aktivitas fisik sehari-hari karena pembelajaran lebih banyak berlangsung daring dari rumah dan terbatasnya aktivitas bermain di luar selama masa pandemi Covid-19. Hal ini menyebabkan zat gizi yang perlu dikeluarkan oleh tubuh tidak seimbang dengan zat gizi yang masuk.

Perlu adanya upaya agar orang tua agar lebih memperhatikan pemenuhan gizi anak agar dapat menghindari akibat dari gizi lebih kegemukan dan obesitas ini seperti penyakit degeneratif meliputi diabetes, jantung koroner, hipertensi, osteoporosis, dan kanker di masa akan datang. Peningkatan pengetahuan merupakan hal yang sangat penting dalam upaya meningkatkan status gizi anak (Septikasari, 2018). Selain faktor pengetahuan, hasil penelitian Aziza 2021 menunjukkan pendapatan orang tua juga memengaruhi status gizi anak pada masa pandemi Covid-19. Pendapatan orang tua ini memengaruhi ketersediaan pangan dan pemenuhan gizi 
seimbang pada anak setiap hari (Aziza \& Mil, $\underline{2021)}$.

\section{Hubungan Kebiasaan Sarapan Pagi dengan Status Gizi}

Hasil penelitian menunjukkan tidak terdapat hubungan antara kebiasaan sarapan pagi dengan status gizi anak di Sekolah Dasar negeri 48 Pekanbaru. Temuan ini sejalan dengan hasil penelitian Miko (2016) yang menilai Hubungan Pola Makan Pagi dengan Status Gizi Pada Mahasiswi Poltekkes Kemenkes Aceh, yang mendapatkan bahwa tidak ada hubungan antara pola makan pagi dengan status gizi mahasiswi Poltekkes Kemenkes Aceh (Miko \& Dina, 2016).

Berbeda dengan hasil penelitian yang didapatkan Utama (2018) bahwa terdapat perbedaan signifikan status gizi antara siswa sekolah dasar negeri dan sekolah dasar swasta $\mathrm{p}=0,034$. Serta didapatkan hubungan signifikan ( $\mathrm{p}=0,002)$ pada kebiasaan sarapan pagi siswa sekolah dasar negeri dan sekolah dasar swasta (Utama et al., 2018).

\section{KESIMPULAN DAN SARAN}

Siswa Sekolah Dasar Negeri 48 Kota Pekanbaru mayoritas mempunyai kebiasaan sarapan pagi yang baik. Mayoritas siswa memiliki status gizi lebih dengan kategori gemuk dan obesitas (berdasarkan IMT/U), selebihnya berstatus gizi baik (normal).

Kebiasaan sarapan pagi siswa yang baik tidak sebanding dengan status gizi normal yang dimiliki. Mayoritas siswa dengan kebiasaan sarapan pagi baik, memiliki status gizi lebih dengan kategori gemuk dan obesitas. Secara statistik temuan ini menunjukkan tidak ada hubungan bermakna antara kebiasaan sarapan pagi dengan status gizi siswa di Sekolah Dasar Negeri 48 Kota Pekanbaru.

\section{DAFTAR PUSTAKA}

Adolphus, K. et al. (2016). The effects of breakfast and breakfast composition on cognition in adults. Advances in Nutrition, 7(3), 576S-589S. https://doi.org/10.3945/ an.115.010231.

Aghadiati, F. (2019). Hubungan Pengetahuan Ibu dengan Pola Menu Sarapan dan Kebiasaan Sarapan pada Anak Sekolah Dasar. Jurnal Kesehatan Terpadu (Integrated Health Journal), 10(2), 5662. https://doi.org/10.32695/jkt.v10i2.46.
Aziza, N. A., \& Mil, S. (2021). Pengaruh Pendapatan Orang Tua terhadap Status Gizi Anak Usia 4-5 Tahun pada Masa Pandemi COVID-19. Golden Age: Jurnal Ilmiah Tumbuh Kembang Anak Usia Dini, 6(3), 109-120. https://doi.org/10.14421/ jga.2021.63-01.

Direktorat Jenderal Bina Gizi dan KIA. (2014). Pedoman Gizi Seimbang.

Hardinsyah, H., \& Aries, M. (2016). Jenis Pangan Sarapan Dan Perannya Dalam Asupan Gizi Harian Anak Usia 6-12 Tahun Di Indonesia. Jurnal Gizi Dan Pangan, 7(2), 89. https://doi.org/ 10.25182/jgp.2012.7.2.89-96.

Hayati, M., Ketut, S. I., \& Kristiawati. (2018). Analisis Faktor Orang Tua terhadap Status Gizi Balita Pendekatan Teori health Belief Model. 031, 282.

Jackson, J., Williams, R., McEvoy, M., MacDonald-Wicks, L., \& Patterson, A. (2016). Is higher consumption of animal flesh foods associated with better iron status among adults in developed countries? A systematic review. Nutrients, 8(2), 1-27. https://doi.org/ $10.3390 /$ nu8020089.

Judarwanto, W. (2016). Mengatasi Kesulitan Makan pada Anak. Puspa Swara.

Kemenkes RI. (2020). Panduan Gizi Seimbang pada Masa Pandemi Covid 19.

Miko, A., \& Dina, P. B. (2016). Hubungan Pola Makan Pagi dengan Status Gizi pada Mahasiswi Poltekkes Kemenkes Aceh. AcTion: Aceh Nutrition Journal, 1(2), 83. https://doi.org/10.30867/action.v1i2.15

Perdana, F., \& Hardinsyah, H. (2013). Analisis Jenis, Jumlah, Dan Mutu Gizi Konsumsi Sarapan Anak Indonesia. Jurnal Gizi Dan Pangan, 8(1), 39. https://doi.org/ 10.25182/jgp.2013.8.1.39-46.

Pritasari, Damayanti, D., \& Lestari, N. (2017). Gizi Dalam Daur Kehidupan. Kemenkes RI.

Sekretariat Jenderal Kementerian Kesehatan RI. (2016). Profil Kesehatan Indonesia Tahun 2015.

Septikasari, M. (2018). Status Gizi Anak dan Faktor yang Mempengaruhi (Ed 1). UNY Press.

Utama, L. J., Sembiring, A. C., \& Sine, J. G. L. (2018). Perilaku sarapan pagi kaitannya dengan status gizi dan anemia pada anak sekolah dasar. Jurnal Gizi Indonesia (The 
Indonesian Journal of Nutrition), 7(1), 63-68. https://doi.org/ 10.14710/ jgi.7.1.63-68.

Wiradnyani, L. A. A., Pramesthi, I. L., Raiyan, M., Nuraliffah, S., Nurjanatun, Februhartanty, J., Ermayani, E., \& Iswarawanti, D. N. (2019). Gizi dan
Kesehatan Anak Usia Sekolah Dasar (Ed

2). Southeast Asian Ministers of Education Organization, Regional Centre for Food and Nutrition (SEAMEO RECFON). 